\title{
Erratum to: Mechanical transmission of Tomato leaf curl New Delhi virus to cucurbit germplasm: selection of tolerance sources in Cucumis melo
}

\author{
Carmelo López · María Ferriol · Maria Belén Picó
}

Published online: 22 December 2016

(C) Springer Science+Business Media Dordrecht 2016

\section{Erratum to: Euphytica (2015) 204:679-691 DOI 10.1007/s10681-015-1371-x}

Due to an unfortunate turn of events, part of the acknowledgment section was omitted from the original publication and the funding agency was therefore not properly acknowledged. The correct representation of the acknowledgment section is published here and should be treated as definitive.
The online version of the original article can be found under doi:10.1007/s10681-015-1371-x.

\section{López · M. B. Picó ( $\square)$}

Institute for the Conservation and Breeding of Agricultural Biodiversity (COMAV), Universitat Politècnica de València (UPV), Camino de Vera, s/n, 46022 Valencia, Spain

e-mail: mpicosi@btc.upv.es

\section{Ferriol}

Instituto Agroforestal Mediterráneo (IAM-UPV),

Universitat Politècnica de Valencia, Camino de Vera, s/n, 46022 Valencia, Spain

\begin{abstract}
Acknowledgements This work was supported by Project E_RTAE2013-00020-C04-03 from the Spanish Instituto Nacional de Investigacion y Tecnología Agraria y Alimentaria (INIA) co-funded with FEDER 2014-2020 funds. Authors thank M. Arnedo (Ramiro Arnedo S.A.) for providing zucchini infected plants from affected greenhouses in Almería.
\end{abstract}

